\title{
The Impact of Relationship-Oriented and Task-Oriented Management Styles on Organizational Climate in Tehran's High Schools
}

\author{
Zahra Gholami \\ Department of Educational Management, College of Psychology and Educational Science \\ Central Tehran Branch, Islamic Azad University, Tehran, Iran \\ Email: gholami_raha84@yahoo.com
}

Received: June 14, 2016 Accepted: July 16, 2016 Published: July 28, 2016

doi:10.5296/ijld.v6i3.9794 URL: http://dx.doi.org/10.5296/ ijld.v6i3.9794

\begin{abstract}
The present study was aimed to examine the effect of relationship-oriented and task-oriented management styles on organizational atmosphere in Tehran's high schools in 2016. Research method was practical in terms of objective; and it was survey-descriptive in terms of data collection. The statistical population consisted of all high school managers in Tehran, from which 322 individuals were selected as sample size, using Cochran Formula and Stratified Cluster Sampling Method. Data collection was done based on Halpin and Croft's Organizational Climate questionnaire, and Bardtz and Matenkas's management Style questionnaire. After collecting the questionnaires, data were examined and analyzed using Structural Equation Modeling method and Smart PLS software in two sections: 1) measurement model and 2) structural section. In the first section, technical features of the questionnaires included reliability, convergent validity, divergent validity, which were examined through PLS. In the second section, the software's significance coefficients were used for examining research hypotheses. Finally, findings approved of the effect of relationship-oriented and task-oriented management styles on organizational climate in Tehran's high schools.
\end{abstract}

Keywords: Management style, Relationship-oriented, Task-oriented, Organizational climate 


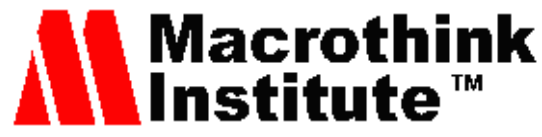

\section{Introduction}

Today, in the third millennium, advancement in organizations is rooted in optimal use of human resources. Paying attention to this huge source in human resources management, considering employees' needs and problems and providing a proper climate in organizations are factors affecting organizations' success and progress (Schimmel, 2009).

On the other hand, management in educational organizations is of great importance, and it is one of the most sensitive, difficult, and fruitful activities; because with the help of those managers who are capable and know principles, theories, and management styles, it is possible to revolutionize organizations' faces by programming, coordinating, and organizing activities and by getting the most out of various resources and realizing set goals (Ghioomi, 2015).

A healthy and favorable climate certainly has a positive effect on teachers and managers' professional relationships, leading to intimate and close connections between them. On the contrary, organizational climate in unhealthy and improper schools may bring about an environment filled with doubt and stress, leading to failure in any cooperative and group management style (Shiri, 2015).

In addition, today's world is full of complexities which have caused organizations to face numerous challenges in the process of growth and perfection. Hence leaders as planners and organizers of humanity are faced with various difficulties and hardships (Richardson, Millage \& Lane, 2014).

However, today, the main issue is that all leaders do not behave in the same management style; leadership style is an insight and behavioral pattern which helps managers to have their inferiors obey their rules. In fact, leadership style refers to worldview, thinking style, and leader's personality when facing organizational issues, by affecting inferiors (Yusefnia Araloo, 2014).

Hence, considering the importance of management styles and the role that these styles play in organizational climate especially in the education system, and considering the fact that a limited number of researches have been conducted in connection to examining the effect of management styles in educational organizations such as schools, the present study aims to examine the effect of relationship-oriented and task-oriented management styles on organizational climate. Finally, since Tehran's high schools try to maintain and enhance their position, and achieve their goals, they need to focus on organizational climate and factors affecting it. One of the important factors is management. Hence, the present study has attempted to examine the effect of management style (relationship-oriented - task-oriented) on organizational climate in Tehran's high schools in order to answer the questions, "How does management style (relationship-oriented - task-oriented) affect organizational climate in Tehran's high schools?" 


\section{Theoretical Concepts and Research Background}

In this section, we examine the literature and background connected to the two styles of management, i.e. relationship-oriented and task-oriented:

\subsection{Organizational Climate}

In the third millennium, in order to perform their duties in the best possible way, schools must possess favorable climate. The topic of schools' climate and its effects on general performance in recent decades has attracted many scholars' attention. School climate is a broad term which is referred to as teachers' perception of their public working environment and school; and it is affected by formal and informal organization, individuals' personality and organizational leadership, and generally attributes inside organizations, which distinguish similar schools and affect their employees (Shiri, 2015).

On the other hand, the education system is an organization which is particularly sensitive in all societies. This sensitivity is more due to the fact that internal functions are exposed to the public eye and are judged by the public. Social revolutions and advancements require an effective education system. Hence, different researches in this field can recognize existing inadequacies and faults, and they can also make it possible to alleviate them. In that sense, organizational climate examinations are exclusive to educational institutes and schools. Our education system needs an organizational climate in which children and adolescents become thoughtful, creative, innovative, and confident individuals, not weak social entities who do not know where to go in life (Zahedi, 2003).

By definition, organizational climate includes organizational structure and environmental conditions ruling organizations, which comprise activities such as selecting and installing experts, monitoring, organizing, reward system, inter-personal relationships, laws and regulations ruling organizations, style of assigning responsibilities, and supporting employees in organizations. In addition, organizational climate is referred to as internal features which distinguish organizations and affect their behavior. Different studies have been done on organizational climate, and different dimensions have been defined for this inter-organizational factor. Here, we can refer to studies done by Halpin and Croft (1963), which define eight dimensions for organizational climate: 1) hindrance, 2) disengagement, 3 ) intimacy, 4) consideration, 5) aloofness, 6) thrust, 7) production emphasis, 8) group spirit (Halpin and Croft, 1963; according to Ebrahimi, 2014).

\subsubsection{Brief Definitions of Organizational Climate}

- Group spirit: is referred to as a situation in which teachers enjoy group work and they feel committed to coworkers and students;

- Hindrance: is referred to as teachers and managers' feeling of a climate in which managers assign heavy loads of unnecessary work to teachers. These affairs are obstacles to their main activities, i.e. teaching.

- Disengagement: is teachers' intention to not participate in scholastic affairs, which is also referred to as lack of commitment. Teachers waste the time and negatively criticize 
their coworkers.

- Intimacy: is referred to as warm, friendly, social, and family relationships between managers and teachers.

- Consideration: This dimension is referred to as managers' friendly and warm behavior. With this feature, managers would like to behave in humanistic styles.

- Disengagement: is referred to as managers' impersonal and formal behavior. They keep away from their employees and would like regulations to rule schools climate. Managers behave according to rules; they are norm-oriented; and they emphasize structural dimensions.

- Thrust: This dimension refers to managers' dynamic behavior. Managers try to motivate their employees by showing themselves as proper work patterns.

- Production emphasis: shows managers' close supervision and autocratic behavior in schools (Ebrahimi, 2012).

In this regard, considering the fact that organizational climate is a controllable factor in the education system, the fact that it is more changeable compared to organizational climate, and the fact that by changing it, school officials provide better opportunities for educational activities, it must be noted that examining factors affecting it can be of great importance, because those schools which possess favorable climates help teachers have motivation and interest in their work, leading to higher effectiveness (Shiri, 2015).

\subsection{Management Style (relationship-oriented and task-oriented)}

The term "style" is referred to as a type of behavior through which managers dominate inferiors. According to Fiddler, management style is an individual's need infrastructure which motivates their behavior in different situations. Therefore, management style focuses on endurance of goals and needs in different situations. As Edgar Shin stated, management style is the type of managers' hypotheses about human nature, management style, and their ultimate purpose for mental covenant, which must hold between employees and organizations (Alami and Barzi, 2009: 31).

In other words, an individual's personality or management style is behavioral patterns which they exhibit when navigating others. This pattern generally includes duty-focused or relationship-oriented behaviors, or a combination of these two (Rezayi, 2013).

In addition, it must be noted that the importance of educational managers' style and its role in optimizing schools is known to everybody. However, educational researchers and policy makers have always belied that managers are the main pillars of school optimization; and in line with the definition and interpretation of this term, they have stated that schools' management style is different from other leadership terms common in other organizations (Murphy \& Datnow, 2003).

Many studies have been done connected to different management styles, but researches which have been done since 1940 have shown that the role of management is twofold: 
1) Relationship-oriented behaviors which pay attention to interests, feelings, and satisfaction in task oriented and relationship-oriented members of groups.

2) Task-oriented behaviors which pay more attention to organizational goals than members' needs.

In other words, relationship-oriented style is a boundary within which managers hold personal relationships between themselves and group members by opening communication paths, assigning responsibility, and providing opportunities for inferiors to exploit potential abilities. This behavior is recognized by social support, friendship, and trust; however, task-oriented style is a boundary within which leaders organize their group members and define the type of functions, the time of doing them, and the way they should be done (Ahmadi and Bazrafshan, 2014: 75).

Teachers use relationship-oriented and task-oriented management styles in their work too; relationship-oriented management style is a cooperative style through which managers give their inferiors options and engage them in decision making. On the contrary, in task-oriented management style, managers determine inferiors' authority and they to some extent use autocracy (Zare, 2010).

In the following, reviewing studies and researches on sources such as universities and centers providing scientific and research sources shows that a small number of studies have been conducted in Iran; however, it can be said that because discussions of management style effect (relationship-oriented and task-oriented) on organizational climate, like many other discussions, are in connection to human and social sciences. Hence, in each of them, certain studies have been done and findings have been used in certain places and times, which are as follows:

In their study, Fidan\& Oztürk (2015) stated that organizational climate for innovation with organizational output includes ideas, considerable innovations, and employees and customers' satisfaction, and complex practical services and programs. Arora \& et al (2013) found that organizational climate, besides factors such as management and leadership style, employees and supervisors' relationships, and engaging in decision making, can play an effective role in individuals' commitment to organizational objectives. In their study, Chen \& Huang (2008) found that more supportive and open organizational climates lead to stronger performances than limited and degrading climates. Finally, Kumar \& Giri (2007) found that there is a positive relationship between occupational satisfaction, organizational commitment, and organizational climate.

In Iran, Aftaabsavar et al (2015) concluded that there is a significant relationship between relationship-oriented and task-oriented management styles with creativity. In their study, Ahmadi and Bazrafshan (2014) showed that relationship-oriented and task-oriented management styles are able to predict variables such as organizational health and occupational stress. In the following, Fakhar Shahr Reza (2013) found that there is a positive and significant relationship between relationship-oriented management style and teachers' empowerment; and that there is a reverse and significant relationship between managers' 
task-oriented management style and teachers' empowerment. In addition, there is a positive and reverse relationship between relationship-oriented management style and with each empowerment component. And there is a reverse and significant relationship between task-oriented management style and each empowerment component. Additionally, in a study called "examination of the relationship between management styles and teachers' occupational-mental satisfaction, Bakhshayesh and Azarniad (2012) concluded that school teachers' occupational satisfaction and mental health much depend on managers' management style; and managers who have a humanistic attitude will can enhance their inferiors' occupational satisfaction and mental health. Zareh (2010) found that there is a significant relationship between relationship-oriented management style and teachers' occupational satisfaction and motivation. In addition, there is a reverse relationship between task-oriented management style and teachers' occupational satisfaction and motivation. Rahpeima (2010) stated that there is a significant relationship between management styles (relationship-oriented and task-oriented) and mental health with creativity in a multifold way; and the combination of these variables is able to predict creativity in organizations. Yazdan Panah et al (2009) found that there is a relationship between management style and time management. In addition, subsidiary results show that there is a significant relationship between autocratic, supportive, cooperative, and success-oriented style with managers' time management. Alami and Barzi's findings (2009) also showed that there is significant relationship between relationship-oriented management style and teachers' emotional commitment, normative, and intellectual commitment. And there is not a significant relationship between task-oriented management style and teachers' emotional commitment, normative commitment, and intellectual commitment. Finally, Beydokhti and Parvaresh (2008) approved of the relationship between organizational climate and management style; they also approved of its effects on elementary school teachers.

From the above-mentioned, it seems that management styles can affect schools' organizational climate. Hence, considering the fact that Tehran's education system experiences many financial and non-financial disadvantages because of not examining the effect of management style (relationship-oriented and task-oriented) on organizational climate in Tehran's high schools in different levels, this has been deemed as an essential weakness and challenge in the strategic plan of educational development, and certain decisions have been made in order to do a scientific and educational research for pathology and scientific problem-solving methods. In addition, in this paper, after reviewing literature and research background, we are aiming to examine the effects of management styles (relationship-oriented and task-oriented) on organizational climate in Tehran's high schools.

\section{Development of Model and Hypotheses}

Effect of management style (relationship-oriented and task-oriented) on organizational climate in Tehran's high schools.

Since relationship-oriented management style emphasizes personal dimensions, it pays attention to employees' motivations and needs; and it is based on the assumption that organizational success depends on employees working in the organization rather than on 
accurate performance of organizational rules and expectations. It must not be supposed that relationship-oriented or individual-focused style, compared to task-oriented or organization-focused style, pays less attention to organizational goals. In relationship-oriented style, emphasis on personal dimensions and paying attention to individuals' motivations are considered to be the fastest ways to realize organizational goals. In this management style, it is made possible for individuals to choose the most appropriate ways to perform duties. In this case, because duty performance relies on individuals' tastes and intentions, organizational expectations lose their formality and they might be obstacles to duty performance. Obvious challenges in such a management style will most probably be personality conflicts. The key to success in this style of management is adapting behavior to employees' personal motivations and effectiveness. On the contrary, in task-oriented management style pays attention to organizational expectations by relying on norms; and it is based on the assumption that in order to realize organizational goals, we can combine procedures, instructions, and regulations with duties, expectations, and organizational roles. It also requires employees to follow them carefully in order to perform their duties. According to this style, if organizational roles are defined clearly, and if everybody takes responsibility for performing their duties, organizations' expected results will be obtained. In this style of management, inferiors are to perform duties accurately; and managers set or apply rules. Challenges of this management style are role challenges. In this style of management, success factors are effectiveness and behavioral adaptability with organizational expectations (Alami and Barzi, 2009: 33).

On the other hand, the most important factor which affects human relationships in schools is organizational climate. Organizational climate is not tangible or visible, but it is everywhere like air, and it affects every organizational event; and it is also affected by events (Shiri, 2015).

Finally, today's education system's managers can use relationship-oriented and task-oriented styles, either of which has certain consequences for employees. Relationship-oriented management style refers to the extent to which managers might have personal relationships with inferiors by communicating with them, giving those options, and providing opportunities for them in order to use potential abilities. Task-oriented management style refers to the extent to which leaders might organize and define the roles and duties of group members (Zareh, 2010).

\subsection{Based on the above-mentioned, the following hypotheses are presented}

- $\mathrm{H}_{1}$ : relationship-oriented management style affects organizational climate in Tehran's high schools.

- $\mathrm{H}_{2}$ : task-oriented management style affects organizational climate in Tehran's high schools. 


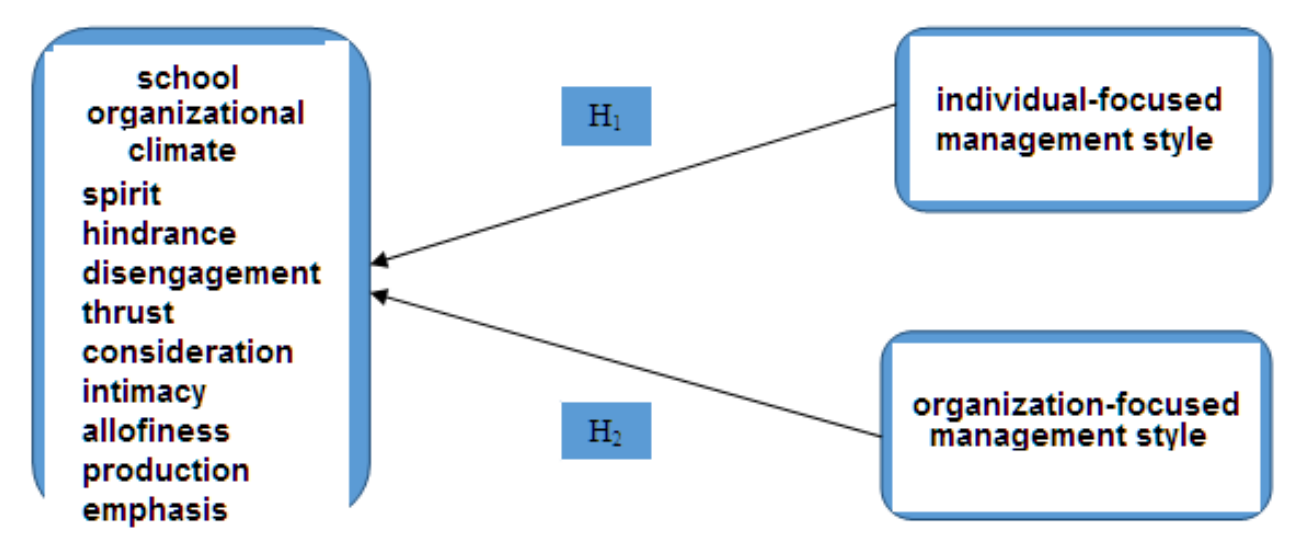

Figure 1: Conceptual model of research

\section{Methodology}

Since the data connected to the effect of relationship-oriented and task-oriented management styles on organizational climate in schools are collected through questionnaires, the present study is a practical and quantitative research. In terms of environment, it is a field research. And in terms of definiteness of variables and relationships between them, it is deterministic. In addition, considering the topic, this research is survey-descriptive. Descriptive and inferential statistics methods have been used in different stages. The statistical population consisted of all managers with management backgrounds of over 20 years in Tehran's high schools (643 individuals). Considering the fact that for each manager, some experienced teachers were questioned, the whole population size 2000, from which 322 teachers and managers were selected sample size, using Cochran Formula; and using Stratified Cluster Sampling method, they were given questionnaires. First, Tehran's education areas were divided into 5 regions: south, west, east, north, and west; then from each part, one region, and from each region, a number of high schools were selected randomly. To collect data, two standard questionnaires were used: Halpin and Croft's organizational climate questionnaire (1963), according to Shiri (2015); and Bardtz and Matenkas's management style questionnaire (1969), according to Ahmadi and Bazrafshan (2014). These questionnaires had 32 and 35 items, respectively. The items were scored on a Likert 5-point scale (1=very low, $2=$ low, $3=$ not very low, 4=high, 5=very high). In order to calculate validity of the questionnaires, content validity was used. Hence, they were approved by a number of university professors and necessary modifications were applied. For construct validity, Least Partial Squares method and Smart PLS software were used. Construct validity has been divided into two parts: convergent validity and divergent validity. Considering the fact that AVE (Average variances Extracted) has been greater than 0.5 for all variables. Hence, convergent validity of model items was approved. In addition, findings showed that divergent validity of research tool is approved. Besides, reliability coefficient (CR) and Cronbach's alpha were calculated to be greater than 0.7 , which approves the reliability of research tool. Tool psychometric results for research variables have been presented in the following table: 
Table 1: Tool psychometric results for research variables

\begin{tabular}{|c|c|c|c|c|c|c|}
\hline dimension & variable & source & $\begin{array}{l}\text { Number } \\
\text { of items }\end{array}$ & alpha & AVE & $\mathbf{C R}$ \\
\hline \multirow{8}{*}{$\begin{array}{l}\text { Organizational } \\
\text { climate }\end{array}$} & Spirit & \multirow{8}{*}{$\begin{array}{l}\text { Halpin and } \\
\text { Croft } \\
(1963) \\
\text { according } \\
\text { to Shiri } \\
(2015)\end{array}$} & 4 & 0.780 & 0.684 & 0.852 \\
\hline & Hindrance & & 4 & 0.904 & 0.645 & 0.951 \\
\hline & Intimacy & & 4 & 0.761 & 0.863 & 0.853 \\
\hline & Disengagement & & 4 & 0.766 & 0.637 & 0.749 \\
\hline & Consideration & & 4 & 0.861 & 0.803 & 0.811 \\
\hline & Aloofness & & 4 & 0.841 & 0.78 & 0.903 \\
\hline & Thrust & & 4 & 0.74 & 0.837 & 0.749 \\
\hline & $\begin{array}{l}\text { Production } \\
\text { emphasis }\end{array}$ & & 4 & 0.607 & 0.763 & 0.808 \\
\hline \multicolumn{2}{|c|}{$\begin{array}{l}\text { relationship-oriented management } \\
\text { style }\end{array}$} & \multirow{2}{*}{$\begin{array}{l}\text { Bardtz and } \\
\text { Matenkas } \\
(1969) \text {, } \\
\text { according } \\
\text { to Ahmadi } \\
\text { and } \\
\text { Bazrafshan } \\
(2014)\end{array}$} & 15 & 0.901 & 0.884 & 0.899 \\
\hline \multicolumn{2}{|c|}{ task-oriented management style } & & 20 & 0.890 & 0.894 & 0.901 \\
\hline
\end{tabular}

Finally, it must be noted that in order to analyze and interpret data, inferential and descriptive statistics were used, including analysis of covariance structures (structural equation modeling). 


\section{Al Macrothink \\ International Journal of Learning and Development \\ ISSN 2164-4063 2016, Vol. 6, No. 3}

\section{Data Analysis}

\subsection{Sample Description}

In the following table, sample has been summarized in terms of demography.

Table 2: Demographic data of sample

\begin{tabular}{|l|l|l|l|}
\hline $\begin{array}{l}\text { Demographic } \\
\text { features }\end{array}$ & class & frequency & Percentage \\
\hline \multirow{4}{*}{ Gender } & Male & 99 & 98 \\
\cline { 2 - 5 } & Female & 2 & 2 \\
\hline \multirow{4}{*}{ Academic degree } & Associate degree & 9 & 9 \\
\cline { 2 - 5 } & BA & 56 & 55 \\
\cline { 2 - 5 } & MA and upper & 36 & 36 \\
\hline \multirow{3}{*}{ age } & Under 35 years & 5 & 5 \\
\cline { 2 - 5 } & 43 to 45 & 11 & 84 \\
\cline { 2 - 4 } & $45+$ & 85 & 11 \\
\hline
\end{tabular}

Inferential statistics section shows that among all school managers of Tehran's high schools, who were selected as sample size, 98 percent were men and 2 percent were women. In addition, classification of respondents was done based their age; most individuals were $45+$; and most of them had BA degrees.

\subsection{Testing model and research hypotheses}

In this stage, the cause-and-effect relationship between relationship-oriented and task-oriented management styles on organizational climate in Tehran's high schools was examined in the form of a structural model. As it can be seen from the following figure, the effect of relationship-oriented and task-oriented management styles on organizational climate in Tehran's high schools is significant. 


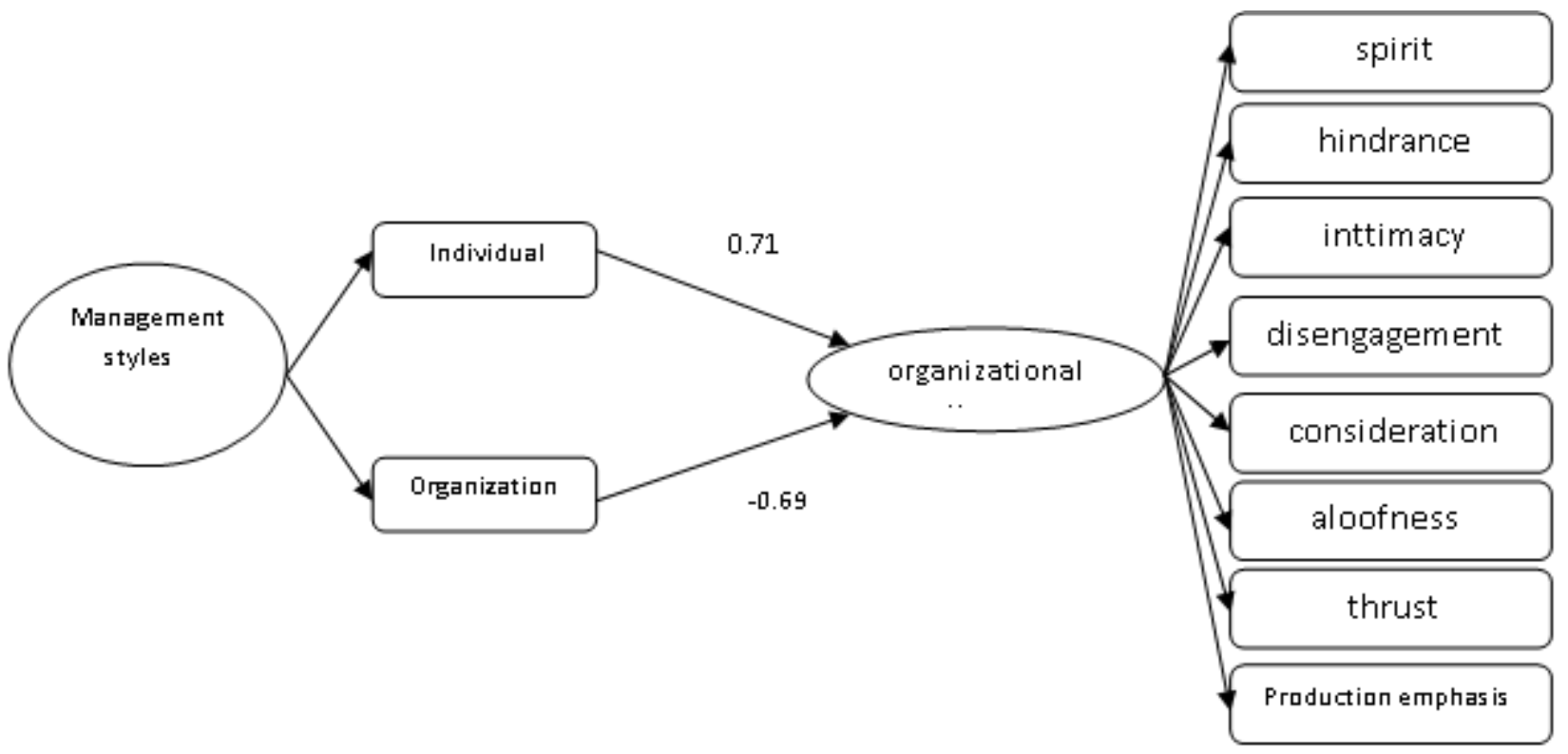

Figure 2: Causal effect coefficients of research model

Figure 2 depicts research model's causal effect coefficients and the effect of the main variable of relationship-oriented and task-oriented management styles on organizational climate in Tehran's high schools. PLS output approves of main hypotheses as well as subsidiary hypotheses, which have been presented in table 3. Since all values of " $\mathrm{t}$ " are greater than 1.96, all hypotheses are approved.

Table 3: Examination of research hypotheses

\begin{tabular}{|l|l|l|l|}
\hline hypotheses & $\begin{array}{l}\text { Standardized } \\
\text { coefficients } \\
\text { "t" }\end{array}$ & $\begin{array}{l}\text { Values of } \\
\text { result }\end{array}$ \\
$\begin{array}{l}\text { relationship-oriented management style } \rightarrow \\
\text { organizational climate in Tehran's high schools }\end{array}$ & 0.71 & 18.05 & accepted \\
\hline $\begin{array}{c}\text { task-oriented management style } \rightarrow \\
\text { organizational climate in Tehran's high schools }\end{array}$ & -0.69 & 18.65 & accepted \\
\hline
\end{tabular}

\section{Conclusion and Propositions}

Generally, today's world is full of complexities which have caused numerous problems for the education system as well as educational institutes in terms of growth and perfection, leading education managers in all levels as planners, organizers, and leaders in educational fields to face various challenges. In such conditions, examining the effect of using relationship-oriented and task-oriented management styles on problem-solving in schools' organizational climate can be helpful; in line with this, the present study has been aiming to examine the role of relationship-oriented and task-oriented management styles in organizational climate in Tehran's high schools in order to meet schools' future needs. In the 
following, we express and interpret research hypotheses.

Findings approved of the positive effect of relationship-oriented management style on organizational climate in Tehran's high schools. Since relationship-oriented management style emphasizes personality, teachers' personal motivations and intentions pay attention to schools' employees and students; hence, this style, by emphasizing personality and paying attention to individuals' motivations, provides an organizational climate filled with intimacy and spirit in schools, and it facilitates the fastest way to realize educational goals. In fact, considering the fact that this management style makes it possible for all individuals to select the most appropriate method to perform duties, it provides the opportunity to improve and enhance organizational climate in schools. In such an organizational climate, duty performance in schools depends on individuals' tastes and intentions; hence, they feel more intimate and they higher spirits when doing assigned duties.

In the second hypothesis, findings approved of the negative effect of task-oriented management style on organizational climate in Tehran's high schools. Since task-oriented management style, relying on norms, does not care about educational expectations, and because it is based on the assumption that in order to realize educational goals, we can combine procedures, instructions, and regulations with duties, expectations, and roles of schools, it requires teachers, employees, and students to follow them when performing their duties; hence, an inflexible organizational climate is based on classical theories of management. In fact, based on this style, if schools' roles are defined clearly and if everybody takes responsibility for their duties, desired results will be obtained. This shows that in inflexible organizational climates, teachers and all employees and students are to follow regulations carefully, and managers set or apply regulations. Hence, it is common to see a heavy atmosphere in such schools.

Finally, findings of researchers such as Alami and Barzi (2009), Beydokhti and Parvaresh (2008) approve of the present study's findings referring to the effect of relationship-oriented and task-oriented management styles on schools' organizational climate. Hence, considering the approval of the present study's findings, it must be noted that if schools' organizational climate is selected in a way that it suits educational needs, there will be a climate in which teachers and employees are happy and lively, leading to more commitment and loyalty and higher spirits and performance; in such a climate, they go to work with enthusiasm and they take pride in working in the environment; educational goals are clear to most of them and problems are solved actively and realistically; there is cooperation between teachers and schools; there is no conflict between them; individuals are honest and they trust one another; decisions lead to more effectiveness; they possess open and successful communication networks; teachers, informally and regardless of their titles and positions, cooperate in order to solve problems. 


\section{References}

Aftaabsavar, D., Hosseini, S.M., Naeemi, S.H. and Abutorabi, B.S. (2015). Examination of relationship between management styles and mental health with creativity. Hormozgan province: The first Islamic gathering and mental health.

Ebrahimi, M. (2012). Relationship between organizational climate and organizational trust with teachers' occupational involvement in Delijan's high schools, in 2011- 2012. MA thesis, Saveh's Islamic Azad University.

Ahmadi, A. and Bazrafshan, A. (2014). Relationship between management styles and mental health with employees' job stress. New-Rahyaft Scientific Quarterly of Educational Management, fifth year, number 2, pages 73-89.

Bakhshayesh, A. and Azarniad, A. (2012). Examination of the relationship between management styles and teachers' job and mental satisfaction. Research and scientific Quarterly (New-Rahyaft) of Educational Management (Novel ideas in educational sciences), no 4, pages 25-41.

Rahpeima, S. (2010). Relationship between management style (relationship-oriented and task-oriented) and mental health with teachers' creativity in Fasa's high schools. MA thesis, Marvdasht's Islamic Azad University.

Rezayi, A. (2013). Relationship between cooperation knowledge and managers' management style with parents' participation in Saveh's high schools (2012-2013). MA thesis, Saveh's Islamic Azad University.

Zareh, M. (2009). Examination of the relationship between management style (relationship-oriented and task-oriented) and job satisfaction with high school teachers' motivation. MA thesis, Marvdasht's Islamic Azad University.

Zahedi, Sh. (2003). Systemic analysis of factors affecting entrepreneurship. Entrepreneurship and advanced technology articles, Tehran: Tehran's University Publications.

Shiri, M. (2015). Relationship between organizational climate and happiness with Saveh's high-school second-grade teachers' liveliness. MA thesis, Saveh's Islamic Azad University, Research and Science unit.

Alami, M., Barzi, A.M. (2009). Examination of the relationship between management styles and teachers' organizational climate in Bukan's education system. Sociology Publications, first year, No 3, pages 27-50.

Fakhar Shahr Reza, M. (2013). Examination of the relationship between preparatory schools' management styles (relationship-oriented and task-oriented) and teachers' empowerment. MA thesis, Allameh Tabatabyi University.

Yazdan Panah, Z., Hesari, M., Baratali Monfaredi, R. and Asgarzadeh, H. (2009). Relationship between managers' management styles and time management in Bojnurd's high schools. Islamic Azad University's Education Bulletin in Bojnurd. No 21, pages 153-167. 


\section{Macrothink}

International Journal of Learning and Development

ISSN 2164-4063 2016, Vol. 6, No. 3

Yusefnia Araloo, A. (2014). Examination of the relationship between managers' management styles and parents' participation level in girls' elementary school, region 19, Tehran's education. MA thesis, Tehran's central Islamic Azad University.

Arora, N., Nuseir, T. M. \& Arora, R. (2012). "Study-based moderators influencing the relationship between organizational climate and employee's organization commitment: A meta-analysis", Euro Med Journal of Business, 7 (2), pp. 201-220.

Chen, C \& Huang, T. (2008). The relationship among ethical climate types, facets of job satisfaction and the three components of organizational commitment: A study of Nurses in Taiwan, Journal of Business Ethics, 80(3), pp.565-581.

Fidan, Tuncer, Inci Oztürk, (2015). The Relationship of the Creativity of Public and Private School Teachers to their Intrinsic Motivation and the School Climate for Innovation, Social and Behavioral Sciences, Volume 195, 3 July 2015, Pages 905-914.

Halpin, A.W and Croft, D.B. (1963). "The organizational climate of schools", Chicago: Midwest administration center, university of Chicago.

Kumar, B.P \& Giri, N.V. (2007). Organizational commitment, climate and job satisfaction, an empirical study, The Icfai, Journal of Organizational Behavior.

Richardson, J., Millage, P., Millage, J., \& Lane, S. (2014). The effects of culture on leadership styles in China, Germany, and Russia. Journal of Technology Management in China, 9(3).

Murphy, J, \& Datnow, A. (2003). Leadership lessons from comprehensive school reforms. Thousand Oaks, CA: Corwin press.

Schimmel, J. (2009). Development as happiness: The subjective perception of happiness and UNDP's analysis of poverty, wealth and development, Journal of Happiness Studies, 11, 95-111.

\section{Copyright Disclaimer}

Copyright for this article is retained by the author(s), with first publication rights granted to the journal.

This is an open-access article distributed under the terms and conditions of the Creative Commons Attribution license (http://creativecommons.org/licenses/by/3.0/). 